\title{
EDITORIAL
}

\section{Treaty Override or: Beware of the Beginning}

Helmut Becker, Deloitte \& Touche GmbH, Düsseldorf

Treaty override is a technical term which was invented in the United States and has spread around the world. It means that the rules of a double taxation agreement can be superseded by a subsequent national law, making the treaty rules ineffective.

Some European countries - among them Germany attacked treaty override as unlawful and immoral, in the past, because they had not overridden treaties themselves. However, in the meantime some of them have dramatically changed their mind. Now they behave as if treaty override is a minor misdemeanour, justified by the fact that others are doing the same. They overlook or ignore the fact that treaty override is nothing more than a breach of contract.

A tax treaty represents an international agreement between the two contracting states, which is transferred into national law through the ratification process. From that point in time it shares the fate of all the other national laws, and can be altered or amended by a later national law. If this is the case, it might be legal under national law, but the international agreement has not disappeared: it still exists and is still valid.

Such an agreement requires faithfulness and loyalty: pacta sunt servanda. Each contracting party can expect the other to comply with the agreement and not to contravene it through its national legislation. If a state does not adhere to this rule, this constitutes a breach of contract and a serious violation of international law.

Unfortunately, this breach of contract cannot be rectified. The International Court in The Hague could render a judgment, however, only if both sides agree. And who has ever heard of two wrongdoers voluntarily asking to become the subjects of a tribunal? Therefore, in practice, such a breach of contract remains unpunished. Unfortunately, it seems that treaty override has become the norm, and cases in this field are increasing, with more and more countries contributing to the degeneration of the law. But does the wrongdoing of one country justify that of another? Is a civilized country entitled to consider an international breach of contract? Has national law a higher ranking than international law? Would we accept that treaty override penetrates other areas? Would we agree that a state overrides the GATT? Would this also apply to the NATO agreements?

If the answer to only one of these questions is 'no', then there is only one consequence: beware of the beginning! 